\title{
GAYA KEPEMIMPINAN, MOTIVASI KERJA DAN KINERJA GURU DI PONDOK PESANTREN
}

\author{
Syamsul Hidayat ${ }^{1)}$, Nani Rohaeni ${ }^{2}$, Muhammad Saleh ${ }^{3)}$ \\ ${ }^{1}$ Prodi Manajemen, Sekolah Tinggi Ilmu Ekonomi Bina Bangsa Banten \\ E-mail: mastersyah@gmail.com \\ ${ }^{2}$ Prodi Manajemen, Sekolah Tinggi Ilmu Ekonomi Bina Bangsa Banten \\ E-mail: nanirohaeni.nr09@gmail.com \\ ${ }^{3}$ Prodi Manajemen, Sekolah Tinggi Ilmu Ekonomi Bina Bangsa Banten \\ E-mail: abigifar165@gmail.com
}

\begin{abstract}
This study examines the analysis factors that influence teacher's performance at pondok pesantren Al-Mubarok. Based on theory, several variables has been constructed. They are leadership style and work motivation are predictors of performance. This research was executed in pondok pesantren Al-Mubarok with 60 participants. The results supported work motivation has strong predictive to teacher's performance, but leadership style has not influence to teachers's performance at pondok pesantren Al-Mubarok.
\end{abstract}

\section{Keywords: leadership style, work motivation, and performance}

\section{PENDAHULUAN}

Pondok Pesantren sebagai Lembaga Pendidikan Islam berbeda dengan pendidikan lainnya baik dari aspek sistem pendidikan maupun unsur pendidikan yang dimilikinya. Perbedaan dari segi sistem pendidikannya, terlihat dari proses belajarmengajarnya yang cenderung sederhana dan tradisional, sekalipun juga terdapat pesantren yang bersifat memadukannya dengan sistem pendidikan modern.

Salah satu tujuan pendidikan adalah untuk menciptakan manusia yang berkualitas. Kualitas manusia yang dibutuhkan oleh bangsa Indonesia pada masa yang akan datang adalah yang mampu menghadapi persaingan yang semakin ketat dengan bangsa lain di dunia. Kualitas manusia Indonesia tersebut dihasilkan melalui penyelenggaraan pendidikan yang bermutu.

Tuntutan perkembangan jaman 'memaksa' pesantren untuk berbenah diri agar dapat mengikuti perubahan tersebut, namun tetap memegang teguh jiwa kepesantrenan dengan tradisi dan karakteristiknya yang khas sebagai lembaga Islam. Sumber daya manusia pesantren pun tidak luput dari penilaian kinerjanya, kinerja yang baik akan menghasilkan sebuah pengakuan bahwa lembaga pesantren memiliki kredibilitas pendidikan bermutu yang ada di Indonesia yang dapat diperhitungkan di kelas nasional dan internasional. 
Ciri yang paling esensial bagi suatu pesantren adalah adanya seorang kyai. Kyai pada hakekatnya adalah gelar yang diberikan kepada seseorang yang mempunyai ilmu di bidang agama dalam hal ini agama Islam. Terlepas dari anggapan kyai sebagai gelar yang sakral, maka sebutan kyai muncul di dunia pondok pesantren. Keberadaan kyai dalam pesantren sangat sentral sekali. Suatu lembaga pendidikan Islam disebut pesantren apabila memiliki tokoh sentral yang disebut kyai. Jadi kyai di dalam dunia pesantren sebagai penggerak dalam mengemban dan mengembangkan pesantren sesuai dengan pola yang dikehendaki. Di tangan seorang kyailah pesantren itu berada, oleh karena itu kyai dan pesantren merupakan dua sisi yang selalu berjalan bersama.

Kyai dan guru secara emosional mempunyai hubungan yang erat dalam pembinaan para santrinya, kiai akan menempatkan guru yang mempunyai pengetahuan yang lebih tinggi dari guru lain. Sehingga akan di tempatkan pada posisi yang lebih tinggi lagi dalam jabatan pesantren tersebut. Dari hal tersebut bahwa ada pengaruh yang tak terpisahkan antara gaya kepemimpinan seorang kiyai dan motivasi yang di berikan oleh kiyai kepada guru yang mengajar di pesantren. Dan biasanya 'kata-kata kiyai' lebih didengar oleh guru dari pada orang lain yang menyuruh.

Guru merupakan elemen kunci dalam sistem pendidikan, khususnya di sekolah. Semua komponen lain, mulai dari kurikulum, sarana-prasarana, biaya, dan sebagainya tidak akan banyak berarti apabila esensi pembelajaran yaitu interaksi guru dengan peserta didik tidak berkualitas. Semua komponen lain, terutama kurikulum akan "hidup" apabila dilaksanakan oleh guru. Begitu pentingnya peran guru dalam mentransformasikan input-input pendidikan, sampai-sampai banyak pakar menyatakan bahwa di sekolah tidak akan ada perubahan atau peningkatan kualitas tanpa adanya perubahan dan peningkatan kualitas guru. Maka sangat perlu sekali menjaga motivasi guru supaya tetap bisa menjalankan tugasnya sebagai guru.

Guru dituntut untuk dapat memperlihatkan kinerja yang baik. Peningkatan kinerja guru ini memerlukan beberapa hal seperti motivasi yang tinggi, kompetensi yang memadai, kepemimpinan yang baik dan lingkungan kerja yang mendukung dosen untuk dapat meningkatkan kinerjanya.

\section{KAJIAN LITERATUR DAN PENGEMBANGAN HIPOTESIS}

\section{Kepemimpinan}

Kepemimpinan menurut Terry dalam Davis (1985) "Leadership is the relationship in which one person, or the leader, influences others to work togethet willingly on related tasks to attain that which the leader desires", kepemimpinan adalah proses mendorong dan membantu orang lain untuk bekerja dengan antusias guna mencapai tujuan.

Gibson et al. (2003) mendefinisikan kepemimpinan sebagai usaha menggunakan pengaruh untuk mendorong individu mencapai suatu tujuan. Gaya kepemimpinan yang dimaksud adalah teori kepemimpinan dari pendekatan perilaku pemimpin. Dari satu segi pendekatan ini 
masih difokuskan lagi pada gaya kepemimpinan (leadership style), sebab gaya kepemimpinan bagian dari pendekatan perilaku pemimpin yang memusatkan perhatian pada proses dinamika kepemimpinan dalam usaha mempengaruhi aktivitas individu untuk mencapai suatu tujuan dalam situasi tertentu.

Gaya kepemimpinan menurut Mulyasa (2011) adalah cara yang dipergunakan pemimpin dalam mempengaruhi para pengikutnya. Gaya kepemimpinan merupakan suatu pola perilaku seorang pemimpin yang khas pada saat mempengaruhi anak buahnya, apa yang dipilih oleh pemimpin untuk dikerjakan, cara pemimpin bertindak dalam mempengaruhi anggota kelompok membentuk gaya kepemimpinannya

Handoko (1995) menyatakan bahwa dalam kenyataannya pemimpin dapat mempengaruhi moral dan kepuasan kerja, keamanan, kualitas hidup kerja dan terutama tingkat prestasi suatu organisasi. Pemimpin yang efektif adalah yang mempunyai sifat-sifat atau kualitas tertentu yang diinginkan seperti karisma, berpandangan ke depan, intensitas, dan keyakinan diri. Kepemimpinan yang efektif dapat memberikan pengarahan terhadap usaha-usaha semua pekerja dalam mencapai tujuan-tujuan organisasi. Kesuksesan atau kegagalan suatu organisasi selalu dihubungkan dengan kepemimpinan (Reksohadiprodjo dan Handoko, 1992).

Thoha (2007) mengemukakan ada beberapa gaya kepemimpinan, diantaranya adalah gaya kepe-mimpinan situasional, yaitu gaya yang didasarkan pada saling berhubungannya hal-hal berikut ini: 1) jumlah petunjuk dan pengarahan yang diberikan oleh pimpinan, 2) jumlah dukungan emosional yang diberikan oleh pimpinan, 3) tingkat kesiapan atau kematangan para pengikut dalam melaksanakan tugas khusus, fungsi atau tujuan tertentu.

\section{Motivasi Kerja}

Gibson et al. (2003) mendefinisikan motivasi sebagai kekuatan yang mendorong karyawan untuk melakukan sesuatu yang menimbulkan dan mengarahkan perilaku. Motivasi adalah salah satu faktor penentu kinerja. Motivasi terbentuk dari sikap (attitude) seorang pegawai dalam menghadapi situasi kerja. Sedangkan pengertian Kerja menurut Malayu Hasibuan (2010) adalah sejumlah aktivitas fisik dan mental untuk mengerjakan suatu pekerjaan.

Secara keseluruhan motivasi kerja menurut Winardi (2011) adalah suatu kekuatan potensial yang ada dalam diri seorang manusia, yang dapat dikembangkan oleh sejumlah kekuatan luar yang pada intinya berkisar sekitar imbalan moneter, dan imbalan non moneter yang dapat mempengaruhi hasil kinerjanya secara positif atau secara negatif, hal mana tergantung pada situasi dan kondisi yang dihadapi orang yang bersangkutan.

\section{Kinerja Guru}

Robbins (2002) menyatakan bahwa kinerja adalah ukuran mengenai apa yang dikerjakan dan apa yang tidak dikerjakan oleh karyawan. Menurut Mangkunegara (2001) prestasi kerja berasal dari kata job performance atau actual performance yaitu hasil kerja secara kualitas dan kuantitas 
yang dicapai oleh seorang pegawai dalam melaksanakan tugasnya sesuai dengan tanggungjawab yang diberikan kepadanya.

Hamzah B. Uno (2012) menerangkan bahwa Kinerja guru adalah kemampuan guru yang di wujudkan melalui perilaku kompeten dalam menerapkan ide, gagasan dan konsep yang menimbulkan tercapainya tujuan kegiatan belajar mengajar secara tuntas. Kinerja guru sekolah dasar merupakan gambaran hasil kerja yang dilakukan guru sekolah dasar terkait dengan tugas apa yang diembannya dan merupakan tanggung jawabnya. Dalam hal ini, tugas-tugas rutin sebagai guru adalah mengadakan perencanaan, pengelolaan, dan pengadministrasian atas tugas-tugas pembelajaran, serta melaksanakan pengajaran.

\section{Pengaruh Gaya Kepmimpinan dan Motivasi Kerja Terhadap Kinerja Guru}

Penelitian terbaru yang dilakukan oleh Yanuarti dan Suparman (2015) tentang pengaruh gaya kepemimpinan, kepuasan kerja dan komitmen organisasi terhadap kinerja guru menghasilkan kesimpulan secara simultan variabel gaya kepemimpinan, kepuasan kerja dan komitmen organisasi berpengaruh signifikan terhadap kinerja guru SMK Muhammadiyah 1 Wonosari, SMK Muhammadiyah 1 Tepus dan SMK Muhammadiyah 1 Patuk. Kemudian Riyadi (2011) mengungkapkan dalam penelitiannya pengaruh kompensasi finansial, gaya kepemimpinan, dan motivasi kerja terhadap kinerja karyawan bahwa gaya kepemimpinan berpengaruh signifikan terhadap kinerja karyawan dan motivasi kerja berpengaruh signifikan terhadap kinerja karyawan. Badra dan
Badra dan Prawitasari (2005) juga menyatakan bahwa motivasi mempunyai pengaruh yang positif dan signifikan terhadap kinerja dosen tetap pada Akper Sorong. Tampi (2014) menyatakan bahwa gaya kepemimpinan dan motivasi pengaruh positif dan signifikan terhadap kinerja karyawan.

Berdasarkan atas kajian teori diatas, maka hipotesis yang diajukan dalam studi ini adalah :

H1: Gaya Kepemimpinan mempunyai pengaruh yang positif dan signifikan terhadap kinerja guru di Pondok Pesantren.

H2: Motivasi Kerja mempunyai pengaruh yang positif dan signifikan terhadap kinerja guru di Pondok Pesantren.

H3: Gaya Kepemimpinan dan Motivasi Kerja mempunyai pengaruh yang positif dan signifikan secara bersama-sama terhadap kinerja guru di Pondok Pesantren.

\section{METODE PENELITIAN}

\section{Metode Sampling dan Pengumpulan Data}

Populasi dalam penelitian ini adalah seluruh guru di Pondok Pesantren AlMubarok Kota Serang sebanyak 60 orang. Penelitian ini juga disebut penelitian populasi, karena jumlah responden 60 dan kurang dari 100, sehingga dengan jumlah tersebut diambil semua sebagai responden. Oleh karena itu penelitian ini merupakan penelitian populasi.

Penentuan jumlah sampel ini didasarkan pada pendapat Roescoe dalam Sekaran (2003) yang mengatakan bahwa jumlah sampel lebih besar dari 30 dan kurang dari 500 pada kebanyakan penelitian sudah 
terwakili. Pengambilan sampel dilakukan dengan metode convinience sampling. Pengumpulan data dilakukan dengan metode survei dengan menggunakan kuesioner yang disampaikan secara langsung kepada responden.

\section{Model Penelitian}

Pemikiran yang mendasari penelitian ini pada hakekatnya adalah bahwa gaya kepemimpinan dan motivasi kerja akan berpengaruh pada kinerja guru. Seorang guru yang mempunyai motivasi yang tinggi serta gaya kepemimpinan yang baik maka akan semakin tinggi pula kinerjanya. Model penelitian ini dapat digambarkan sebagai berikut :

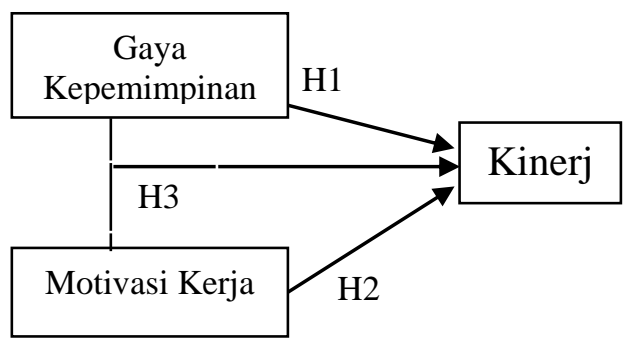

\section{Gambar 1 \\ Model Penelitian}

\section{Definisi Operasional dan Pengukuran Variabel}

Variabel-variabel dalam penelitian ini adalah kinerja sebagai variabel dependen serta gaya kepemimpinan dan motivasi kerja sebagai variabel independen. Variabel-variabel tersebut terlebih dahulu dioperasionalkan agar pengukuran dapat dilakukan.

Kinerja guru adalah kemampuan guru yang di wujudkan melalui perilaku kompeten dalam menerapkan ide, gagasan dan konsep yang menimbulkan tercapainya tujuan kegiatan belajar mengajar secara tuntas. Kemampuan guru meliputi kemampuan merencanakan belajar mengajar, kemampuan melakaksanakan kegiatan belajar mengajar dan kemampuan mengevaluasi. Indikator-indikator tersebut adalah menguasai garis-garis besar penyelenggaraan pendidikan, menyesuaikan analisa materi pelajaran, menyusun program semester, menyusun program atau pembelajaran, tahap pra intruksional, tahap Intruksional , tahap evaluasi dan tindak lanjut, evaluasi normative, evaluasi formatif, laporan hasil evaluasi dan pelaksanaan program perbaikan dan pengayaan

Gaya Kepemimpinan adalah cara yang dipergunakan pemimpin dalam mempengaruhi para pengikutnya. Dimensi gaya kepemimpinan yitu orientasi pada tugas, orientasi pada bawahan dan orientasi pada tingkat kematangan bawahan, akan dijabarkan kedalam 11 item pertanyaan yaitu pengawasan yang ketat, pelaksanaan tugas, memberi petunjuk, mengutamakan hasil daripada proses, melibatkan bawahan dalam pengambilan keputusan, memberi dukungan, kekeluargaan, kerjasama, ketekunan bekerja, aktif dan pengalaman.

Motivasi kerja adalah Dorongan dari dalam diri dan luar diri seseorang untuk melakukan sesuatu yang terlihat dari dimensi internal dan dimensi eksternal. Indikator-indikator tersebut adalah kebutuhan untuk mencapai prestasi, kebutuhan untuk berafiliasi, dan kebutuhan untuk memperoleh kekuasaan. Penjabarannya melalului 11 item pertanyaan yaitu tanggung jawab guru, melaksanakan tugas, memiliki tujuan, umpan balik, senang dalam bekerja, berusaha mengungguli orang lain, berprestasi dari pekerjaanya, kebutuhan 
hidup dan kerjanya, senang memperoleh pujian, insentif dan mendapat perhatian orang lain.

Semua variabel tersebut akan diukur dengan menggunakan Skala Likert. Masing-masing alternatif jawaban akan diberi skor atau nilai 1 untuk jawaban sangat tidak setuju yang berarti sangat buruk, 2 untuk jawaban tidak setuju yang berarti buruk, 3 untuk jawaban netral yang berarti cukup baik, 4 untuk jawaban setuju yang berarti baik, dan 5 untuk jawaban sangat setuju yang berarti sangat baik.

\section{Uji Kualitas Instrumen}

Ada dua syarat penting yang berlaku pada sebuah angket, yaitu keharusan sebuah angket untuk valid dan reliabel. Hasil penelitian dikatakan valid bila terdapat kesamaan antara data yang terkumpul dengan data yang sesungguhnya terjadi pada objek yang diteliti (Sekaran, 2003).

Uji Reliabilitas dilakukan untuk mengukur konsistensi dan stabilitas dari skor (skala pengukuran). Kriteria yang digunakan untuk mengetahui tingkat reliabilitas adalah besarnya nilai cronbach's alpha. Instrumen penelitian disebut handal apabila hasil pengujian menunjukkan alpha lebih besar dari 0,6 (dalam Tjahjono, 2009).

\section{Teknik Analisis Data}

Untuk menguji variabel-variabel yang berpengaruh pada kinerja guru, maka dalam penelitian ini menggunakan analisis regresi linier berganda. Analisis ini untuk menguji signifikansi pengaruh antara lebih dari satu variabel independen terhadap variabel dependen. Perhitungan pada penelitian ini untuk mengetahui pengaruh gaya kepemimpinan dan motivasi kerja pada kinerja guru.

Dalam perhitungan pengolahan data, peneliti mempergunakan alat bantu yang berupa program aplikasi komputer yaitu SPSS versi 16.0.

\section{HASIL DAN PEMBAHASAN}

\section{Hasil Uji Validitas}

Berdasarkan hasil analisis data, semua indikator dari semua variabel dinyatakan valid, berikut untuk pengujian validitas dapat diuraikan pada tabel 1 berikut ini:

Tabel 1

Hasil Pengujian Validitas

\begin{tabular}{|c|c|c|}
\hline $\begin{array}{c}\text { Item } \\
\text { Pertanyaan }\end{array}$ & $\begin{array}{c}\text { Corrected } \\
\text { Item-Total } \\
\text { Correaltion }\end{array}$ & Ket \\
\hline GK_1 & 0,453 & Valid \\
\hline GK_2 & 0,702 & Valid \\
\hline GK_3 & 0,753 & Valid \\
\hline GK_4 & 0,609 & Valid \\
\hline GK_5 & 0,687 & Valid \\
\hline GK_6 & 0,700 & Valid \\
\hline GK_7 & 0,768 & Valid \\
\hline GK_8 & 0,555 & Valid \\
\hline GK_9 & 0,731 & Valid \\
\hline GK_10 & 0,756 & Valid \\
\hline GK_11 & 0,508 & Valid \\
\hline MK_1 & 0,583 & Valid \\
\hline MK_2 & 0,601 & Valid \\
\hline MK_3 & 0,600 & Valid \\
\hline MK_4 & 0,424 & Valid \\
\hline MK_5 & 0,438 & Valid \\
\hline MK_6 & 0,553 & Valid \\
\hline MK_7 & 0,393 & Valid \\
\hline MK_8 & 0,501 & Valid \\
\hline MK_9 & 0,515 & Valid \\
\hline MK_10 & 0,404 & Valid \\
\hline MK_11 & 0,404 & Valid \\
\hline K_1 & 0,751 & Valid \\
\hline K_2 & 0,684 & Valid \\
\hline
\end{tabular}




\begin{tabular}{|c|c|c|}
\hline K_3 & 0,770 & Valid \\
K_4 & 0,791 & Valid \\
K_5 & 0,768 & Valid \\
K_6 & 0,851 & Valid \\
K_7 & 0,657 & Valid \\
K_8 & 0,716 & Valid \\
K_9 & 0,656 & Valid \\
K_10 & 0,646 & Valid \\
K_11 & 0,705 & Valid \\
\hline
\end{tabular}

\section{Hasil Uji Reliabilitas}

Hasil empiris dapat dilihat pada tabel 1 yang menunjukkan bahwa keseluruhan item reliabel atau konsisten sebagai alat ukur.

Tabel 2

Hasil Pengujian Reliabilitas

\begin{tabular}{|c|l|c|}
\hline No & \multicolumn{1}{|c|}{ Variabel } & $\begin{array}{c}\text { Cronbach's } \\
\text { Alpha }\end{array}$ \\
\hline 1 & $\begin{array}{l}\text { Gaya } \\
\text { Kepemimpinan }\end{array}$ & 0,874 \\
\hline 2 & Motivasi Kerja & 0,647 \\
\hline 3 & Kinerja & 0,910 \\
\hline
\end{tabular}

\section{Hasil Respon Kuesioner dan Karakteristik Responden}

Dalam penelitian ini disebarkan 60 buah kuesioner dengan tingkat responsi sebesar $60(100 \%)$. Berdasarkan jenis kelamin, responden 33 orang (55\%) laki-laki dan 27 orang $(45 \%)$ perempuan. Berdasarkan tingkat pendidikan responden 18 orang (30\%) berpendidikan SMA/Sederajat, 4 orang $(6,67 \%)$ berpendidikan Diploma (D3), 37 orang $(61,67 \%)$ berpendidikan Strata 1 (S1), 1 orang $(1,67 \%)$ berpendidikan Strata 2 (S2). Berdasarkan usia responden 20 orang $(33,33 \%)$ sudah bekerja selama 0 s/d 3 tahun, 11 orang $(18,33 \%)$ bekerja selama 4 s/d 6 tahun, 13 orang $(21,67 \%)$ bekerja selama 7 s/d 9 tahun, 16 orang $(26,67 \%)$ bekerja lebih dari 10 tahun.

\section{Deskripsi Variabel Penelitian}

Jawaban responden yang terbanyak untuk variabel gaya kepemimpinan adalah setuju yaitu sebanyak 352 buah atau 53\%, memperlihatkan bahwa jawaban responden yang terbanyak untuk gaya kepemimpinan yang diperlihatkan oleh gaya kepemimpinan di pondok pesantren AlMubarok dalam memimpin dan mengarahkan para guru, terutama dalam tugas pendidikan dan pengajaran adalah untuk kategori baik.

Jawaban responden yang terbanyak untuk variabel motivasi adalah setuju yaitu sebanyak 309 buah atau 47\%, memperlihatkan bahwa jawaban responden yang terbanyak untuk motivasi kerja guru dalam melaksanakan tugasnya dalam pendidikan dan pengajaran adalah untuk kategori tinggi.

Jawaban responden yang terbanyak untuk variabel kinerja adalah setuju yaitu sebanyak 391 buah atau 59\%, memperlihatkan bahwa jawaban responden yang terbanyak untuk kinerja guru dalam melaksanakan tugasnya di bidang pendidikan dan pengajaran adalah untuk kategori baik.

\section{Analisis Regresi Linier Berganda}

Analisis dalam penelitian ini dilakukan dengan menggunakan analisis regresi berganda. Adapun hasilnya ditunjukkan pada tabel 3 . 
Tabel 3

Hasil Regresi Gaya Kepemimpinan dan

Motivasi Kerja terhadap Kinerja Guru

Pondok Pesantren Al-Mubarok

\begin{tabular}{|c|c|c|c|c|c|}
\hline \multirow[b]{2}{*}{ Variabel } & \multicolumn{2}{|c|}{$\begin{array}{l}\text { Unstandardized } \\
\text { Coefficients }\end{array}$} & \multirow{2}{*}{$\begin{array}{c}\begin{array}{c}\text { Standa } \\
\text { rdized } \\
\text { Coeffici } \\
\text { ents }\end{array} \\
\text { Beta } \\
\end{array}$} & \multirow[b]{2}{*}{$t$} & \multirow[b]{2}{*}{ Sig. } \\
\hline & B & Std. Error & & & \\
\hline $\begin{array}{l}\text { gaya_kepemim } \\
\text { pinan }\end{array}$ & .214 & .121 & .204 & 1.775 & .08 \\
\hline motivasi_kerja & .688 & .156 & .506 & 4.408 & .00 \\
\hline Konstanta & 3.663 & 5.399 & & .679 & .50 \\
\hline \multicolumn{3}{|c|}{$\begin{array}{l}\text { F Hitung }=17.939 \\
\text { Sig. } F=0.000 \\
R=0.622 \\
\text { R Square }=0.386 \\
\text { Adjusted R Square }=0.365\end{array}$} & \multicolumn{3}{|c|}{$\begin{array}{l}\mathrm{t} \text {-tabel }=2.002 \\
\mathrm{~F} \text { tabel }=3.159 \\
\text { Tingkat signifikan }=5 \%\end{array}$} \\
\hline
\end{tabular}

Sumber: data primer, diolah

Berdasarkan tabel di atas dapat diartikan sebagai berikut:

1. Persamaan regresi $\mathrm{Y}=3.663+0.214 \mathrm{X}_{1}$ $+0.688 \mathrm{X}_{2}$ yang dapat diinterpretasikan sebagai berikut:

a. Kinerja guru dapat dilihat pada nilai konstanta sebesar 3,663, dengan asumsi tidak memperhitungkan adanya variabel gaya kepemimpinan dan motivasi kerja.

b. Gaya kepemimpinan akan meningkatkan kinerja guru sebesar 0,214, dengan asumsi variabel lainnya konstan, dimana jika gaya kepemimpinan meningkat satu satuan, maka kinerja guru juga akan ikut meningkat sebesar 0,214 satuan, dengan asumsi bahwa variabel lainnya yang tidak diteliti dalam penelitian ini adalah konstan atau tetap.

c. Motivasi kerja akan meningkatkan kinerja guru sebesar 0,688 , dengan asumsi variabel lainnya konstan, dimana jika motivasi kerja meningkat satu satuan, maka kinerja guru juga akan ikut meningkat sebesar 0, 688 satuan, dengan asumsi bahwa variabel lainnya yang tidak diteliti dalam penelitian ini adalah konstan atau tetap.

2. Nilai $\mathrm{R}$ sebesar 0,622 dapat diartikan bahwa hubungan antara variabel $\mathrm{X}$ (gaya kepemimpinan dan motivasi kerja) terhadap variabel Y (kinerja guru) adalah kuat, karena semakin mendekati angka 1.

3. Berdasarkan nilai $\beta$ di atas, dapat disimpulkan bahwa motivasi kerja memiliki pengaruh yang lebih besar terhadap kinerja guru daripada gaya kepemimpinan.

4. Nilai $\mathrm{R}$ Square sebesar 0,385 atau $38,5 \%$ menjelaskan besarnya pengaruh variabel $X$ (gaya kepemimpinan dan motivasi kerja) terhadap variabel $\mathrm{Y}$ (kinerja guru). Nilai R Square di atas dapat diartikan bahwa besarnya pengaruh variabel $\mathrm{X}$ terhadap $\mathrm{Y}$ adalah sebesar 38,5\% sedangkan sisanya $61,5 \%$ dipengaruhi oleh variabel lain di luar variabel yang diteliti dalam penelitian ini seperti atmosfir kerja, budaya organisasi, lingkungan kerja, pendidikan dan variabel lainnya.

\section{Pengujian Hipotesis t}

Pada penelitian ini, nilai $t_{\text {tabel }}$ adalah sebesar 2,002 dengan tingkat signifikan $\alpha$ $=5 \%=0,05$ dengan jumlah responden 60 , dan jumlah variabel bebas adalah 2 variabel.

Berdasarkan tabel 3 di atas, dapat dilihat bahwa nilai t hitung untuk variabel gaya kepemimpinan (X1) adalah 1,775 lebih kecil dari pada nilai $\mathrm{t}_{\text {hitung, dengan }}$ tingkat signifikan lebih besar dari nilai $\alpha$, yakni 0,081. Dengan demikian dapat diartikan bahwa gaya kepemimpinan tidak berpengaruh secara signifikan namun tetap positif terhadap kinerja guru.

Dari tabel 3 juga, dapat dilihat bahwa nilai $t_{\text {hitung }}$ untuk variabel motivasi kerja adalah sebesar 4,408 lebih besar daripada nilai $t_{\text {tabel }}$, yakni 2,002 dengan tingkat 
signifikan 0,000 lebih kecil dari nilai signifikan $\alpha 0,05$. Dengan demikian dapat diartikan bahwa motivasi kerja berpengaruh secara positif dan signifikan terhadap kinerja guru.

Dengan kesimpulan bahwa variabel gaya kepimpinan tidak berpengaruh secara siginifikan terhadap kinerja guru pondok pesantren Al-Mubarok, dengan demikian hipotesis 1 tidak mendapat dukungan empiris dalam penelitian ini. Tabel 3 juga memperlihatkan bahwa variabel motivasi kerja mempunyai pengaruh terhadap kinerja guru pondok pesantren AlMubarok, dengan demikian hipotesis 2 mendapat dukungan empiris dalam penelitian ini.

\section{Pengujian Hipotesis F}

Pada penelitian ini, nilai $F_{\text {tabel }}$ adalah 3,159 dengan tingkat $\alpha$ sebesar $5 \%=0,05$ dimana jumlah responden pada penelitian ini adalah 60 responden, dengan variabel bebas berjumlah 2 variabel.

Berdasarkan hasil analisis data dengan menggunakan SPSS Version 16.0 dapat dilihat nilai $F_{\text {hitung }}$ adalah 17,939 dengan tingkat signifikan 0,000. Dengan demikian dapat diartikan bahwa secara bersamasama variabel $\mathrm{X}$ (gaya kepemimpinan dan motivasi kerja) berpengaruh terhadap variabel $Y$ (kinerja guru), dimana $F_{\text {hitung }}>$ $\mathrm{F}_{\text {tabel }}$ dengan tingkat signifikan $<$ dari nilai $\alpha 5 \%$.

Dengan kesimpulan bahwa variabel gaya kepimpinan dan motivasi kerja secara bersama-sama berpengaruh terhadap kinerja guru pondok pesantren AlMubarok, dengan demikian hipotesis 3 mendapat dukungan empiris dalam penelitian ini.

\section{Pembahasan}

\section{Pengaruh Gaya Kepemimpinan terhadap Kinerja Guru}

Hipotesis 1 yang mengatakan bahwa gaya kepemimpinan tidak mempunyai pengaruh yang signifikan terhadap kinerja guru namun memiliki pengaruh positif. Dapat disimpulkan bahwa tingkat gaya kepemimpinan di pondok pesantren AlMubarok tidak akan serta merta meningkatkan kinerja guru.

Berkaitan hal itu, pondok pesantren adalah lembaga sosial-keagamaan, di pimpinan oleh seorang kiai, tokoh kharismatik yang disegani oleh semua unsur yang ada di pondok pesantren baik santri, guru, dan wali santri serta masyarakat luas. Secara umum guru-guru di pondok pesantren Al-Mubarok tidak memiliki masalah dengan gaya kepemimpinan seorang kiai, karena prinsip yang ada di pesantren adalah mematuhi semua yang di katakan oleh kiai. Di sisi lain, manajerial kiai kurang dapat mendongkrak kinerja guru. Namun akan tetap memiliki kedudukan yang paling atas di setiap hati seorang guru tersebut.

Hipotesis 1 tidak terbukti dan tidak mendukung penelitian terdahulu yang dilakukan oleh Riyadi (2011). Sehingga semakin baik atau buruknya gaya kepemimpinan yang diterapkan di pondok pesantren Al-Mubarok, maka tidak akan berpengaruh pada kinerja guru.

\section{Pengaruh Motivasi Kerja terhadap Kinerja Guru}

Berdasarkan hasil penelitian yang diperoleh, maka $\mathrm{H} 2$ diterima untuk variabel motivasi kerja. Nilai signifikansi 
tersebut masih berada di bawah nilai signifikansi yang ditetapkan yaitu 0.005 dan positif. Dengan demikian secara parsial motivasi kerja berpengaruh signifikan terhadap kinerja guru pondok pesantren Al-Mubarok. Hal ini memberi arti bahwa dengan motivasi kerja yang tinggi, akan memberikan dampak positif pada peningkatan kinerja guru.

Hipotesis 2 terbukti dan mendukung penelitian terdahulu yang dilakukan oleh Badra dan Prawitasari (2005). Sehingga semakin tinggi motivasi kerja yang dimiliki guru pondok pesantren AlMubarok, maka akan berpengaruh pada kinerja guru.

Berkaitan dengan motivasi kerja guru, dengan guru memiliki teman-teman seprofesi yang saling mendukung dalam bekerja dapat meningkatkan semangat bekerja yang akhirnya motivasinya semakin tinggi, memberikan pelayanan dan pengajaran yang terbaik kepada murid sehingga murid merasa senang maka guru tersebut akan meningkatkan kinerjanya.

\section{Pengaruh Gaya Kepemimpinan dan Motivasi Kerja terhadap Kinerja Guru}

Hipotesis 3 yang mengatakan bahwa gaya kepemimpinan dan motivasi kerja mempunyai pengaruh yang signifikan terhadap kinerja guru pondok pesantren Al-Mubarok dapat diterima. Dapat disimpulkan bahwa dengan adanya gaya kepemimpinan yang baik dan motivasi kerja yang tinggi akan meningkatkan kinerja guru.

Hipotesis 3 mendukung penelitian terdahulu yang dilakukan oleh Tampi (2014). Gaya kepemimpinan seseorang dapat dinilai sesuatu yang dapat memberikan efek kepada guru ditambah nilai-nilai kepesantrenan yang kulturalisagamis dapat menjadikan sebuah nilai kepatuhan kepada pemimpin. Kebutuhan guru yang terpenuhi selama bekerja di pondok pesantren Al-Mubarok dapat pula meningkatkan kinerja guru, guru akan semakin bekerja dengan baik dan giat sehingga diharapkan menghasilkan lulusan yang terbaik pula demi generasi yang akan mendatang.

\section{KESIMPULAN}

Temuan dalam penelitian ini menunjukkan bahwa kinerja merupakan faktor yang penting bagi para guru pondok pesantren Al-Mubarok. Motivasi kerja penting dipertimbangkan dalam menjelaskan kinerja ini. Apabila dosen mempunyai motivasi kerja yang tinggi serta didukung dengan kepemimpinan yang baik maka akan dapat meningkatkan kinerja mereka. Gaya kepemimpinan dalam penelitian ini tidak berpengaruh pada kinerja. Hal ini bisa menunjukkan perlunya perhatian yang serius dari pemimpin kepada guru-guru, gaya kepemimpinan harus bisa jelaskan dengan baik kepada guru, artinya aspek manajerial perlu di tingkatkan.

Secara teoritis temuan ini memberikan pemahaman pentingnya pengaruh gaya kepemimpinan dan motivasi kerja terhadap kinerja guru pondok pesantren AlMubarok. Berkaitan dengan dunia praktik, pondok pesantren dan lembaga pendidikan swasta tempat guru bekerja sebaiknya memperhatikan faktor-faktor yang mempengaruhi kinerja guru, sehingga dapat mengambil kebijakan yang tepat untuk dapat meningkatkan kinerja guru yang dipekerjakan. 


\section{DAFTAR PUSTAKA}

Davis, K. dan Newstroom, J.W. 1985. Perilaku Dalam Organisasi, Alih Bahasa: Agus Dharma. Erlangga. Jakarta.

Gibson, James L., John M. Ivancevich, James H. Donnelly Jr., and Robert Konopaske. 2003. Organization : Behavior, Structure, and Processes, $11^{\text {th }}$ Ed. McGraw-Hill. New York.

Mulyasa. 2009. Manajemen Berbasis Sekolah Konsep, Strategi, dan Implementasi. Remaja Rosdakarya. Bandung.

Handoko, T.H. 1995. Manajemen, Edisi Kedua. BPFE. Yogyakarta.

Reksohadiprodjo, Sukanto dan Handoko, T.H. 1992. Organisasi Perusahaan: Teori, Struktur, dan Perilaku, Edisi Kedua, BPFE. Yogyakarta.

Thoha, M. 2007. Kepemimpinan dalam Manajemen: Suatu Pendekatan Perilaku, Raja Grafindo Persada. Jakarta.

Hasibuan, SP. Hasibuan. 2010. Organisasi \& Motivasi Dasar Peningkatan Produktivitas. Bumi Aksara. Jakarta.

Winardi. 2011. Motivasi \& Pemotivasian Dalam Manajemen. Rajawali Press. Jakarta.

Mangkunegara, A. P. 2001. Manajemen Sumber Daya Manusia Perusahaan. Remaja Rosdakarya. Bandung.

Robbins, S.P. 2002. Perilaku Organisasi : Konsep, Kontroversi, Aplikasi, Jilid I, Edisi Indonesia. Prenhallindo. Jakarta.

Hamzah B. Uno. 2012. Teori Motivasi \& Pengukurannya analisis di bidang pendidikan. Bumi Aksara . Yogyakarta.

Yanuarti dan Suparman. 2015. Pengaruh Gaya Kepemimpinan, Kepuasan Kerja, dan Komitmen Organisasi, terhadap Kinerja Guru Pada SMK
Muhammadiyah Kabupaten Gunung Kidul. JBTI. 5 (2): 58-70 .

Riyadi, S. 2011. Pengaruh Kompensasi Finansial, Gaya Kepemimpinan, dan Motivasi Kerja terhadap Kinerja Karyawan pada Perusahaan Manufaktur di Jawa Timur. Jurnal Manajemen dan Kewirausahaan. 13 (1): 40-45.

Badra, I Wayan dan Prawitasari, J.E. 2005. Hubungan antara Stress dan Motivasi dengan Kinerja Dosen Tetap pada Akper Sorong, Working Paper Series, No. 8, Januari 2005. KMPK UGM. Yogyakarta.

Tampi, B.J. 2014. Pengaruh Gaya Kepemimpinan dan Motivasi terhadap Kinerja Karyawan pada PT. Bank Negara Indonesia, Tbk Regional Sales Manado. Journal “Acta Diurna” III (4): 1-20.

Sekaran, U. 2003. Research method for business: A skill building approach. 4th edition, John Wiley \& Sons. New York-USA.

Tjahjono, H.K. 2009. Metode Penelitian Bisnis 1.0. VSM - Magister Manajemen UMY. Yogyakarta. 